\title{
Impact of Time Spent in Front of Screens and Frequency of Risk Behaviours According to Type of Screen: A Cross Sectional Study in Teenagers
}

\author{
Stéphanie Mignot1, Pauline Pourrat1, Pierre Ingrand2, Anne-Laure Heintz ${ }^{1}$, \\ Nemat Jaafari ${ }^{3}$, Philippe Binder ${ }^{1}$ \\ ${ }^{1}$ Department of General Practice, School of Medecine, University of Poitiers, Poitiers, France \\ ${ }^{2}$ Department of Epidemiology \& Biostatistics, School of Medecine, University of Poitiers, Poitiers, France \\ ${ }^{3}$ Intersectoral Clinical Psychiatry Pierre Deniker, Academic Hospital Henri Laborit, Poitiers, France \\ Email: stephanie.mignot@univ-poitiers.fr
}

How to cite this paper: Mignot, S., Pourrat, P., Ingrand, P., Heintz, A.-L., Jaafari, N., \& Binder, P. (2019). Impact of Time Spent in Front of Screens and Frequency of Risk Behaviours According to Type of Screen: A Cross Sectional Study in Teenagers. Psychology, 10, 1776-1789.

https://doi.org/10.4236/psych.2019.1012116

Received: July 16, 2019

Accepted: September 27, 2019

Published: September 30, 2019

Copyright (๑) 2019 by author(s) and Scientific Research Publishing Inc. This work is licensed under the Creative Commons Attribution International License (CC BY 4.0).

http://creativecommons.org/licenses/by/4.0/

\begin{abstract}
The time spent in front of various technology screens during adolescence could be linked to risk behaviours. Our study, carried out in June 2012, was designed to show that this correlation differs not only depending on sex but also according to the type of screen being used. Method: A cross-sectional survey was conducted on 1235 schoolchildren, aged 15, from 90 different schools in the Poitou-Charentes region. The questions asked were based on the Health Behaviour in School-aged Children Survey. Questions on the amount of time spent daily either in front of a television, a computer, on video games and mobile phones were added on. Three sample subgroups were defined according to the frequency of six risk behaviours (smoking, drunkenness, cannabis consumption, early sexual intercourse, fights and suicide attempts). Results: Our total sample comprised 92315 -year-olds: 468 girls and 455 boys: $74.7 \%$ of the pupils were registered in the schools selected. The correlation between time spent in front of various technology screens and frequency of risk behaviours varied according to type of screen but not according to sex. Cellphone use resulted in the highest correlation amongst all teenagers: $\mathrm{OR}=9.40[6.1-14.4]$. Amongst boys, no excess risk was found whilst watching the television, and there is only moderate risk when playing video games $(\mathrm{OR}=2.11[1.14-3.91])$ or whilst using the computer to surf the internet $(\mathrm{OR}=2.21[1.13-4.34])$. Amongst girls, risk grew when using the computer to surf the internet $(\mathrm{OR}=3.31[1.61-6.78])$ and playing video games $(\mathrm{OR}=5.84[1.65-20.6])$. Conclusion: These results suggest that questioning teenagers on screen use could represent an approach to risk behavior that would complement other screening tests.
\end{abstract}




\section{Keywords}

Teenagers, Risk Behaviour, Smartphone, Screens, Suicide Attempts

\section{Background}

Over the last 20 years, multimedia technologies have become increasingly time-consuming in the social lives of adolescents (Rideout, Roberts, \& Foehr, 2010). In the United States, the age group from 12 to 17 years uses the internet the most, as $77 \%$ of these youth have a cell phone and $63 \%$ have stated that they send text messages every day (Lenhart, Hitlin, \& Madden, 2005) with a median of 60 a day (Lenhart, 2012). In France (2013), among 12-to-17-year-olds, 62\% live in a multi-equipped household: $99 \%$ have a computer at home and $69 \%$ have more than one of them in their household (Bigot, Croutte, \& Daudey, 2013: p. 288); $85 \%$ send text messages in order to "kill time", and those who send the most text messages are also among those who phone the most (Lenhart, 2012). Eight out of 10 teenagers stated that they play video games daily (Ministère de l'Éducation Nationale, de l'Enseignement supérieur et de la Recherche, 2010). Among teenagers aged from 13 to $18,39.6 \%$ of girls and $36 \%$ of boys use a computer to access internet sites, while $15.8 \%$ of girls and $25 \%$ of boys use a computer to play video games (Jousselme, Cosquer, \& Hasssler, 2015: p. 182). More than $60 \%$ of French high school juniors and $50 \%$ of students are aware of their spending more than an hour a day on Facebook, and one out of four is aware of the time spent exceeding two hours a day (Ministère de l'Éducation Nationale, de l'Enseignement supérieur et de la Recherche, 2010). All in all, a considerable amount of time is dedicated to these activities. The teens have difficulties regulating their habits and complying with parental rules: $40 \%$ aged from 13 to 15 stated that they slept with their telephone on, under their pillow (Jousselme, Cosquer, \& Hasssler, 2015: p. 182).

Contrary to a common representation, the contents of the programs viewed do not seem to have any influence on young people, except during childhood (Browne \& Hamilton-Giachritsis, 2005). Given the same time of exposure, there is no current evidence of significant correlation between exposure to violent content during adolescence and physical violence by adolescents (Olson, 2004). On the other hand, the correlation between time spent in front of various screens and psycho-behavioural disorders in teenagers is well-documented. They essentially consist in depression and risk behaviours: alcohol consumption, smoking, substance intake, and early initial sexual intercourse (Richards, McGee, Williams, Welch, \& Hancox, 2010; Busch, Manders, \& de Leeuw, 2013). In somewhat younger children (aged 11 to 13 ), this correlation seems proportional to the time spent in front of computers or video games and certain risk behaviours: intoxications, unprotected sexual intercourse, non-use of seat belts, smoking and drug use (Carson, Pickett, \& Janssen, 2011). 
That much said, excessive exposure to media screens, especially when it involves violence or explicit sexual content, drug usage or alcohol consumption, gives adolescents a false image of the world, increases risk behaviours and alters their capacity to establish quality interpersonal relationships (Villani, 2001). Time spent playing online video games causes a predictive conduct disorder outsourced as anxiety and withdrawal (Holtz \& Appel, 2011).

However, the available studies do not distinguish the level of risk according to type of screen. When evoking the question of time of use, US and Canadian paediatric learned societies recommend that children and adolescents should spend less than 2 hours a day in front of diverse electronic screens (American Academy of Pediatrics, Council on Communications and Media, 2013; Nieman, 2003). However, they do not distinguish level of risk according to type of screen. Researchers are divided between those studying the influence of "on table" screens (television, computer, video games) and those interested in the mobile phone. To our knowledge, there exist no published studies that compare the duration of the use of a mobile phone to other screens and to possible risk behaviours.

The aim of the study was to evaluate whether the correlation between time teenagers spend in front of screens and frequency of risk behaviours differed according to type of screen and user gender.

\section{Material and Methods}

\subsection{Population and Survey Design}

In June 2012, we carried out a cross-sectional survey involving a representative sample of 15-year-old adolescents enrolled in 90 randomly drawn schools from a French region. This age bracket was chosen because it has been the subject of numerous studies (Kokkevi, Rotsika, Arapaki, \& Richardson, 2012) and because it presents the highest rate in France of hospitalization of girls due to suicide attempts (Chan-Chee, 2011).

These entities represent $3 \%$ of the overall French population and are devoid of any ethnic or demographic specificity. Nominative selection of the teenagers was carried out by the statistical bodies of the French national education ministry in government-subsidized private and public schools in accordance with the exigencies proper to the international protocol of the Health Behaviour in School-Aged Children survey (HBSC) (Currie et al., 2010). A total of 1235 fifteen-year-old pupils from different schools in the Poitou-Charentes region were drawn at random.

\subsection{The Self-Questionnaire Used}

The final self-questionnaire included 88 questions and covered the following large-scale themes: physical activity, consumption (tobacco, alcohol, drugs), school life, bullying and violence, family life, relationships with medical professionals, overall health and sexuality. The research team had no access to the tee- 
nagers' medical records or school records.

The anonymous self-administered paper-based questionnaire was filled out in classrooms under test-taking conditions under the responsibility of an investigator and in the presence of a French national education health care assistant. The teenagers were informed that the questionnaire would help to "better understand how youngsters of your age" live and that their responses would be read by the researchers in charge of the survey. Nobody in either the school or the family setting would be allowed to identify the persons having completed an anonymous questionnaire. The teenagers were also told that they would not be taking a test or an examination, and that there existed neither "right" nor “wrong” responses.

\subsection{Variables of Interest}

\subsubsection{Screen Time Definition}

Time spent in front of screens was explored for each screen with 4 separate opening questions: "How many hours per day..." do you usually watch television (including videos and DVDs) during your free time?... Do you usually play video games on a computer or a console (Playstation $\odot$, Xbox $\odot$, Gamecube $\odot$, etc...) during your free time?... Do you usually use a computer to participate in forum discussions ("chats") or surf the Internet or send e-mails, or to do homework during your free time?... How much time do you spend with your friend(s) talking on the phone, or sending text messages?

For each screen, the time spent was segmented on a scale of 8 levels: none, 1/2 hour/day, 1 hour/day, 2 hours/day, 3 hours/day, 4 hours/day, 5 hours/day, 6 hours/day or more. There was one scale for each weekday from Monday to Friday and another for the weekend.

As American and Canadian learned pediatric societies have repeatedly recommended that children and teenagers spend less than 2 hours a day in front of a screen, we postulated that once this time limit is exceeded, a risk exists.

\subsubsection{Definition of Risk Behaviours}

Among the priority risks cited in the YRBS (Youth Risk Behaviour Survey) we have selected 3 behaviours: violence (participation in physical fights, suicide attempts), consumption (tobacco, alcohol, cannabis) and sexual behaviour (early sexual intercourse). For each behaviour the severity level was defined according to its early initiation and/or repetition: "if one smokes at least one cigarette a day"; "if one has consumed alcohol to the point of having been drunk at least 4 times in one's life"; "if one has smoked at least 3 cannabis joints over the last 30 days"; "if one has already had at least one sexual relationship aged 13 or younger"; "if one has participated at least 3 times in a physical fight over the last 12 months"; "if one has made at least two suicide attempts in one's life".

The group was then divided into three smaller groups based on the frequency of reported risk behaviours. The "no risk behaviour" group brought together the teenagers who said they had never engaged in one of the above. The "high risk 
behaviour" group brought together those who reported at least one of the above. The "intermediate risk behaviour" group comprised participants who could not be placed in the "no risk behaviour" group because they had engaged in some violence, consumption or sexual behaviour. But they were not placed in the "high risk behaviour" because they had not engaged in this behaviour as much as the teenagers of the "high risk behaviour" group.

\subsection{Ethics}

As is obligatorily the case in France when surveys are conducted in a school setting, the competent authorities in the French Ministry of Education preliminarily approved the study. Given the French legislation on observational studies, our survey was registered by the National Commission on Informatics and Liberty (CNIL No. 1560423 and No. 7z70310939s), which is mandated to ensure personal data protection and prohibits any search for ethnic differences. A letter of introduction to the survey was preliminarily addressed to all the parents involved, who were given the option to refuse.

\subsection{Statistical Analyses}

The association between overall screen time, type of screen and predictive variables of interest was initially explored by univariate analysis $\left(\mathrm{Chi}^{2}\right.$ test of independence). The significance threshold was set at 0.05 . Results were expressed as percentages. We subsequently carried out a multivariate analysis independently integrating the remaining items that were significantly associated with time spent in front of a screen, and type of screen. We introduced elements for which the association was significant at $20 \%$ as independent variables in a multivariate logistic regression implementing a bottom-up elimination procedure. The adjusted Odds Ratio and its 95\% confidence interval were determined for each factor. Data collection was conducted using Microsoft Excel 2010 (Microsoft corporation; Santa Rosa, CA) and statistical analysis was carried out using SAS৫ software version 9.3 (SAS Institute Inc., Cary, NC, USA).

\section{Results}

Our total sample comprised 92315 -year-olds: 468 girls and 455 boys: $74.7 \%$ of the pupils registered in the selected schools.

The "no risk behavior" group involved $25.4 \%$ of the girls and $23.5 \%$ of the boys, while the "intermediate risk behavior" group included $48.0 \%$ of the girls and $43.7 \%$ of the boys, and finally, the "high risk behavior" group comprised $26.5 \%$ of the girls and $32.7 \%$ of the boys (Table 1 ). The proportion of participants stating that they spent more than 2 hours/weekday in front of a TV or DVD screen was $22 \%$ for the girls and $24 \%$ for the boys, while $7 \%$ of the girls and $21 \%$ of the boys played video games on a computer console, $20 \%$ of the girls and $17 \%$ of the boys used a computer for internet consultation or homework, and lastly, $54 \%$ of the girls and $39 \%$ of the boys used cellphones as a means of communication. 
Table 1. Behaviours of the adolescents according to gender and health risk group.

\begin{tabular}{|c|c|c|c|c|c|c|c|}
\hline \multirow[b]{2}{*}{ Risk Behaviour (RB) } & \multirow[b]{2}{*}{ Frequency } & \multicolumn{3}{|c|}{ GIRLS } & \multicolumn{3}{|c|}{ BOYS } \\
\hline & & $\begin{array}{c}\text { No RB } \\
\mathrm{n}=119 \\
\mathrm{n}(\%)\end{array}$ & $\begin{array}{l}\text { Intermediate RB } \\
\qquad \mathrm{n}=225 \\
\mathrm{n}(\%)\end{array}$ & $\begin{array}{l}\text { High RB } \\
\mathrm{n}=124 \\
\mathrm{n}(\%)\end{array}$ & $\begin{array}{c}\text { No RB } \\
\mathrm{n}=107 \\
\mathrm{n}(\%)\end{array}$ & $\begin{array}{l}\text { Intermediate RB } \\
\qquad \mathrm{n}=199 \\
\mathrm{n}(\%)\end{array}$ & $\begin{array}{c}\text { High RB } \\
\mathrm{n}=149 \\
\mathrm{n}(\%)\end{array}$ \\
\hline \multirow[b]{2}{*}{ Suicide attempts in their lifetimes } & Never & $119(100)$ & $186(83)$ & $56(46)$ & $107(100)$ & $187(95)$ & $119(82)$ \\
\hline & 1 time & 0 & $37(17)$ & $23(19)$ & 0 & $9(5)$ & $17(12)$ \\
\hline Missing data & & 0 & 2 & 2 & 0 & 3 & 4 \\
\hline \multirow{3}{*}{$\begin{array}{l}\text { Participated in a fight over the } \\
\text { last } 12 \text { months }\end{array}$} & No & $119(100)$ & $192(86)$ & $75(61)$ & $107(100)$ & $115(59)$ & $50(34)$ \\
\hline & $<3$ times & 0 & $32(14)$ & $35(29)$ & 0 & $79(41)$ & $45(30)$ \\
\hline & $\geq 3$ times & 0 & 0 & $12(10)$ & 0 & 0 & $53(36)$ \\
\hline Missing data & & 0 & 1 & 2 & 0 & 5 & 1 \\
\hline \multirow{3}{*}{ First sexual intercourse } & Never & $119(100)$ & $170(76)$ & $46(37)$ & $107(100)$ & $142(72)$ & $56(38)$ \\
\hline & $>13$ years & 0 & $53(24)$ & $64(52)$ & 0 & $56(28)$ & $60(41)$ \\
\hline & $\leq 13$ years & 0 & 0 & $14(11)$ & 0 & 0 & $31(21)$ \\
\hline Missing data & & 0 & 2 & 0 & 0 & 1 & 2 \\
\hline \multirow{3}{*}{$\begin{array}{l}\text { Has consumed so much alcohol } \\
\text { as to be completely drunk }\end{array}$} & Never & $119(100)$ & $141(63)$ & $31(25)$ & $107(100)$ & $132(67)$ & $48(32)$ \\
\hline & $<4$ times & 0 & $84(37)$ & $72(58)$ & 0 & $66(33)$ & $41(28)$ \\
\hline & $\geq 4$ times & 0 & 0 & $21(17)$ & 0 & 0 & $60(40)$ \\
\hline Missing data & & 0 & 0 & 0 & 0 & 1 & 0 \\
\hline \multirow{3}{*}{ Has already consumed cannabis } & Never ever & $119(100)$ & $209(94)$ & $61(51)$ & $107(100)$ & $184(94)$ & $64(45)$ \\
\hline & $<3$ joints last $30 \mathrm{~d}$ & 0 & $13(6)$ & $26(22)$ & 0 & $12(6)$ & $22(16)$ \\
\hline & $\geq 3$ joints last $30 \mathrm{~d}$ & 0 & 0 & $33(27)$ & 0 & 0 & $55(39)$ \\
\hline \multirow{3}{*}{ Tobacco smoking } & Never & $119(100)$ & $166(74)$ & $16(13)$ & $107(100)$ & $167(84)$ & $41(28)$ \\
\hline & $<1 /$ day & 0 & $59(26)$ & $26(21)$ & 0 & $32(16)$ & $24(16)$ \\
\hline & $\geq 1 /$ day & 0 & 0 & $82(66)$ & 0 & 0 & $84(56)$ \\
\hline Missing data & & 0 & 0 & 0 & 0 & 0 & 0 \\
\hline
\end{tabular}

\section{Correlation with risk behaviours}

While the proportion of youth in the "high risk behaviour" group spending over $2 \mathrm{~h}$ /weekday on their cellphones or computers was higher among the girls than the boys, their respective rates of use were similar: $(\mathrm{OR}=9.86[5.46 ; 17.8])$ for girls and $(\mathrm{OR}=11.4[5.82 ; 22.2])$ for the boys if we consider cellphone use. As regards video games, however, the direction of the relationship was reversed, $(\mathrm{OR}=5.84[1.65 ; 20.6])$ for the girls and $(\mathrm{OR}=2.11[1.14 ; 3.91])$ for the boys.

Overall, the teenagers who used their cellphones more than $2 \mathrm{~h} / \mathrm{d}$ displayed considerably increased risk behaviours $\left(\mathrm{OR}=9.4\left[\mathrm{CI}_{95 \%}: 6.1\right.\right.$ - 14.4]) as compared to users of other screens; no association was found between television watching and risk behaviour, and there was only a weak link between video game participation or computer use and risk behaviour (Table 2). Taking all the screens into account, cell phone use presented the strongest link between risk behaviours and screens; it is for that reason that we analysed the proportions of "at risk" groups in accordance with time spent on cell phone. As expected, the time spent on a 
Table 2. Correlation between being in front of a screen more than $2 \mathrm{~h} /$ weekday and frequency of risk behaviours at 15 years old and according to gender.

\begin{tabular}{|c|c|c|c|c|c|c|c|c|c|c|c|c|}
\hline \multirow{3}{*}{$\begin{array}{c}\text { Risk } \\
\text { Behaviour }\end{array}$} & \multicolumn{4}{|c|}{ GIRLS } & \multicolumn{4}{|c|}{ BOYS } & \multicolumn{4}{|c|}{ TOTAL } \\
\hline & No & $\begin{array}{c}\text { Interme } \\
\text { diate }\end{array}$ & High & $\begin{array}{l}\text { OR }\left[\mathrm{CI}_{95 \%}\right] \\
\text { High vs No }\end{array}$ & No & $\begin{array}{l}\text { Interme } \\
\text { diate }\end{array}$ & High & $\begin{array}{l}\text { OR }\left[\mathrm{CI}_{95 \%}\right] \\
\text { High vs No }\end{array}$ & No & $\begin{array}{c}\text { Interme } \\
\text { diate }\end{array}$ & High & $\begin{array}{l}\text { OR }\left[\mathrm{CI}_{95 \%}\right] \\
\text { High vs No }\end{array}$ \\
\hline & $\mathrm{N}=119$ & $\mathrm{~N}=225$ & $\mathrm{~N}=124$ & $P$ & $\mathrm{~N}=107$ & $\mathrm{~N}=199$ & $\mathrm{~N}=149$ & $P$ & $\mathrm{~N}=226$ & $\mathrm{~N}=424$ & $\mathrm{~N}=273$ & $P$ \\
\hline Television $^{1}$ & $\begin{array}{c}20 \\
(17 \%)\end{array}$ & $\begin{array}{c}50 \\
(22 \%)\end{array}$ & $\begin{array}{c}31 \\
(25 \%)\end{array}$ & $\begin{array}{c}1.69 \\
{[0.90 ; 3.17]} \\
0.10\end{array}$ & $\begin{array}{c}27 \\
(25 \%)\end{array}$ & $\begin{array}{c}40 \\
(20 \%)\end{array}$ & $\begin{array}{c}39 \\
(27 \%)\end{array}$ & $\begin{array}{c}1.06 \\
{[0.60 ; 1.87]} \\
0.85\end{array}$ & $\begin{array}{c}47 \\
(21 \%)\end{array}$ & $\begin{array}{c}90 \\
(21 \%)\end{array}$ & $\begin{array}{c}70 \\
(26 \%)\end{array}$ & $\begin{array}{c}1.33 \\
{[0.87 ; 2.03]} \\
0.18\end{array}$ \\
\hline $\begin{array}{l}\text { Video } \\
\text { games }^{2}\end{array}$ & $\begin{array}{c}3 \\
(3 \%)\end{array}$ & $\begin{array}{c}12 \\
(5 \%)\end{array}$ & $\begin{array}{c}16 \\
(13 \%)\end{array}$ & $\begin{array}{c}5.84 \\
{[1.65 ; 20.6]} \\
0.0023\end{array}$ & $\begin{array}{c}18 \\
(17 \%)\end{array}$ & $\begin{array}{c}30 \\
(15 \%)\end{array}$ & $\begin{array}{c}44 \\
(30 \%)\end{array}$ & $\begin{array}{c}2.11 \\
{[1.14 ; 3.91]} \\
0.017\end{array}$ & $\begin{array}{c}21 \\
(9 \%)\end{array}$ & $\begin{array}{c}42 \\
(10 \%)\end{array}$ & $\begin{array}{c}60 \\
(22 \%)\end{array}$ & $\begin{array}{c}2.80 \\
{[1.64 ; 4.78]} \\
<0.0001\end{array}$ \\
\hline Computer $^{3}$ & $\begin{array}{c}12 \\
(10 \%)\end{array}$ & $\begin{array}{c}47 \\
(21 \%)\end{array}$ & $\begin{array}{c}33 \\
(27 \%)\end{array}$ & $\begin{array}{c}3.31 \\
{[1.61 ; 6.78]} \\
0.0007\end{array}$ & $\begin{array}{c}14 \\
(13 \%)\end{array}$ & $\begin{array}{c}27 \\
(14 \%\end{array}$ & $\begin{array}{c}37 \\
(25 \%)\end{array}$ & $\begin{array}{c}2.21 \\
{[1.13 ; 4.34]} \\
0.019\end{array}$ & $\begin{array}{c}26 \\
(12 \%)\end{array}$ & $\begin{array}{c}74 \\
(17 \%\end{array}$ & $\begin{array}{c}70 \\
(26 \%)\end{array}$ & $\begin{array}{c}2.69 \\
{[1.65 ; 4.40]} \\
<0.0001\end{array}$ \\
\hline $\begin{array}{l}\text { Mobile } \\
\text { phone }^{4}\end{array}$ & $\begin{array}{c}28 \\
(24 \%)\end{array}$ & $\begin{array}{c}132 \\
(59 \%)\end{array}$ & $\begin{array}{c}92 \\
(75 \%)\end{array}$ & $\begin{array}{c}9.86 \\
{[5.46 ; 17.8]} \\
<0.0001\end{array}$ & $\begin{array}{c}13 \\
(12 \%)\end{array}$ & $\begin{array}{c}72 \\
(37 \%)\end{array}$ & $\begin{array}{c}90 \\
(62 \%)\end{array}$ & $\begin{array}{c}11.4 \\
{[5.82 ; 22.2]} \\
<0.0001\end{array}$ & $\begin{array}{c}41 \\
(18 \%)\end{array}$ & $\begin{array}{c}204 \\
(49 \%)\end{array}$ & $\begin{array}{c}182 \\
(68 \%)\end{array}$ & $\begin{array}{c}9.39 \\
{[6.14 ; 14.4]} \\
<0.0001\end{array}$ \\
\hline
\end{tabular}

${ }^{1}$ Watching television (including video films and DVDs); ${ }^{2}$ Playing on a computer or a console; ${ }^{3}$ Using a computer to participate in "chats", surfing the Internet, sending e-mails, doing homework; ${ }^{4}$ Speaking on the telephone, or sending text messages to friends.

cellphone by 15 -year-olds of the "high risk behaviour" group is distributed on either side of a peak reached at $2 \mathrm{~h} /$ weekday and very largely exceeds that peak at more than $5 \mathrm{~h}$ /weekday. Under $2 \mathrm{~h} /$ weekday spent on cell phone the proportion of teenagers in the "no risk behavior" group was more elevated than in the "high risk behaviour" group. Among the teenagers who declared that they did not spend time on cell phone, the proportion of the "no risk behavior" was 15\%, while, the proportion in the "high risk behaviour" group was less than $5 \%$. On the other hand, the proportion on the "high risk behaviour" group was higher after 4 $\mathrm{h} /$ weekday than in the "no risk behavior" group. For more than $6 \mathrm{~h} /$ weekday, the proportion in the "high risk behaviour" group was $41 \%$ compared to $6 \%$ in the "no risk behavior" group (Figure 1).

\section{Discussion}

The link between risk behavior and screen use at 15 years of age varies highly significantly according to type of screen but very little according to user gender; whatever the sex, it is more elevated with cell phones, otherwise known as smartphones, and does not exist with regard to television.

As in other studies, we found an association between risk behaviors and excessive use of different screens; prevalence of internet addiction varies from 5.4\% in Italy (Pallanti, Bernardi, \& Quercioli, 2006) to $18.3 \%$ in Britain (Niemz, Griffiths, \& Banyard, 2005). Internet addiction has been reported as leading to academic, social, and occupational impairment (Young, 1998). Furthermore, the levels of loneliness (Whang, Lee, \& Chang, 2003), depression (Whang, Lee, \& Chang, 2003; Kim et al., 2006; Dalbudak et al., 2013), compulsivity (Whang, Lee, \& Chang, 2003) 


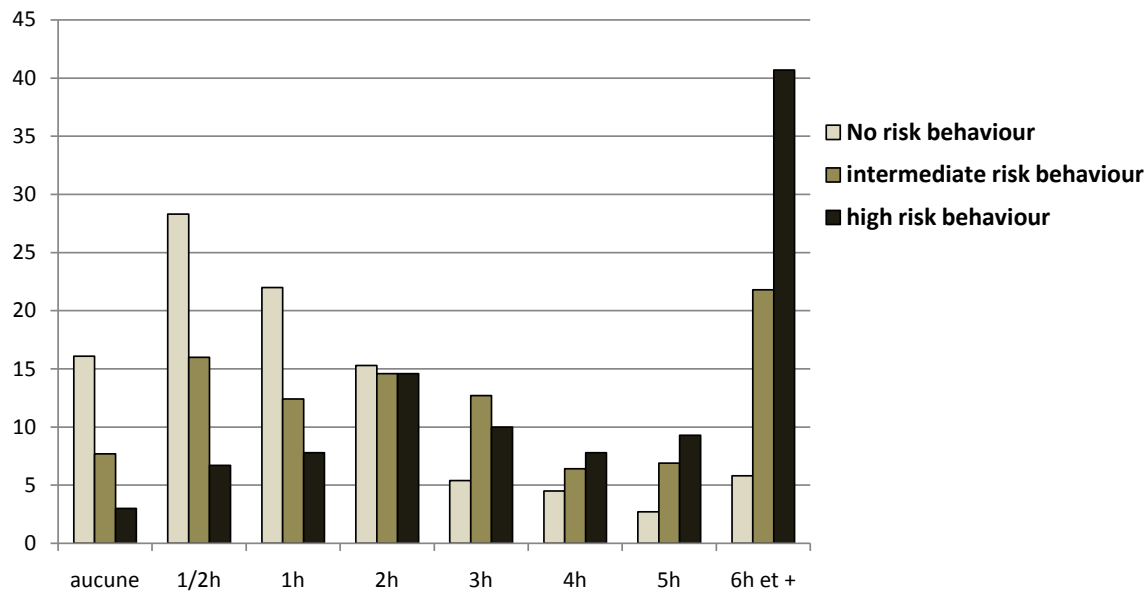

Figure 1. Teenagers rates according risk and time spent on the cell phone.

and suicide ideation (Kim et al., 2006; Fu, Chan, Wong, \& Yip, 2010) are higher in internet addicts as compared to control subjects. Problems are more commonly reported by younger (Widyanto \& McMurran, 2004) subjects.

Several interpretations of the correlation between time spent in front of screens and risk behaviours have previously been published. Some studies show only a small influence of the contents on different behaviours, and increased use of screens tends to evoke boredom, or escape from reality or inability to find another activity. It has also been suggested that excessive time communicating on one's mobile phone reflects a sense of loneliness (Jin \& Park, 2013) or difficulty in expressing one's feelings (Ha, Chin, Park, Ryu, \& Yu, 2008). Functional neuroimaging studies have found some evidence that internet addicts fail to recruit frontal-basal pathways, which are important in inhibiting unwanted actions (Li et al., 2014). In a comprehensive survey on Canadian youth in middle school, Fitzpatick found that videogame usage was the strongest negative correlate of academic achievement and physical activity and made the smallest positive contributions to self-esteem and the consumption of fruits and vegetables. Internet usage made the strongest negative contribution to self-esteem and smaller contributions to physical activity, and academic achievement. Both internet and videogame use made equally small contributions to school connectedness and bullying. Television use generally made the smallest negative contributions to well-being indicators (Fitzpatrick, Burkhalter, \& Asbridge, 2019).

As concerns type of screen, a study conducted in 2013 showed that teenagers who had previously in their life experienced depression were more likely to use their cell phones more frequently than other adolescents (Kang \& Lee, 2014). Another study found that youth with access to the internet on their cell phones were more likely to report having been approached online for sex, to be sexually active, or to have had sex with someone they met online, compared to youth without access to the internet on their cell phones (Rice, Winetrobe, Holloway, Montoya, Plant, \& Kordic, 2015). 


\section{Strengths and Limitations of the Study}

Our results were supported by questionnaire design, rigorous administration and the quality of the data collected. Formulation of the basic questions was derived from the international HBSC questionnaire. Supplementary questions were closely related to the relevant literature. Selection and grouping of young people were conducted properly. Both award and anonymity conditions were successfully fulfilled. The response rate of $75 \%$ of the respondents compared to the theoretical population of 15-year-old pupils provided high statistical power and ensured representativeness of the general population. Moreover, the Poitou-Charentes region is stable and typical of the rest of the country (INSEE, 2012).

However, the investigation was limited to 15 -year-old pupils, and the results cannot be extended, much less extrapolated to other age groups. Our choice was nonetheless rational inasmuch as the highest rate of risk behaviour is found in this age group, and it is increasing daily (Eaton et al., 2012).

That said, we have not verified the teenagers' affirmations, especially as regards their estimates of the time they dedicate to a given activity; what is more, a wish for social desirability tends to privilege favourable self-presentation, and participants may be reluctant to admit risk behaviour; these are the customary limits of self-declaration questionnaires. However, these biases would undoubtedly have been more pronounced in individual interviews; in our survey, they were minimized by the confidentiality of data collection. More generally, self-reported responses present three drawbacks: the above-mentioned wish for social desirability (Crowne \& Marlowe, 1960) and hesitation to declare stigmatised behaviour, and approximate, possibly inaccurate estimates of time spent on a given activity. However, desirability bias and unwillingness to confess time spent in front of diverse screens are usually more marked in consultation than in questionnaire answers. Finally, concerning the estimated period of use, it is the presentation by the young person that matters most, and not a scientifically calculated representation. The aforementioned biases have little incidence on results, and in responses to verbal questioning in general practice, the same basic mechanisms are involved.

However, the responses given in a paper-based questionnaire should be compared with caution to the responses given orally, during a medical consultation.

While the choices of the study's main points were limited, they remained based on classic choices (Eaton et al., 2012). Completeness of risk behaviours does not seem useful insofar as adolescents only rarely manifest a single isolated risk behaviour (Leather, 2009). The choice of putting suicide attempts in the plural (two rather than one) may seem surprising. However, the rate among girls was particularly high (21\%) and is well above that of all the relevant international (Kokkevi, Rotsika, Arapaki, \& Richardson, 2012) or national (Jousselme, Cosquer, \& Hasssler, 2015) studies, a finding which suggests that in many cases, suicide attempts have been under-reported due to fear of attribution of self-abuse 
or aggressive self-harm. In addition, the literature shows that the severity of these attempts has primarily to do with their repetition (Christiansen \& Jensen, 2007). In the final analysis, this is a "lifetime" question, for which the answer should not depend on "the year."

In this questionnaire there were confounding variables that could not be addressed, for instance, amount of parental involvement in their teenage children's screen time, tendencies to externalize or internalize problems, mediating the relationships between screen time and incidence of risk behaviours.

We have deliberately limited our analysis to time spent on weekdays, thereby excluding weekends. Indeed, use of technology screens differs during weekends (Rey-López et al., 2012; Jago et al., 2014). Moreover, exclusion of screen time on weekends represents an educational challenge because it is in competition with the time dedicated to school learning. In the literature, choices for organization of one's spare time are by no means homogeneous. Some studies alternate their focus between weekdays and weekends (Maras et al., 2015; Carson, Pickett, \& Janssen, 2011), while others are limited to certain days of the week, thereby excluding weekends (Grøntved et al., 2015). It also bears mentioning that this cross-sectional study does not attempt to interpret any link between cell phone time and risk behaviour.

These results illustrate the interest during consultations in medical practice of questioning youth and their families on use of screens: Which types? For what length of time? Having become universal among teenagers, screen use seems to invite overuse, and could in some cases serve as a first step to detect potentially "high risk behavior" adolescents. Even the most routine medical consultation can constructively contribute to health education. Moreover, it matters to inform parents that contrary to what they might intuitively tend to think, type of screen and duration of use may be more problematic than the contents disseminated. Even though this issue is not nearly as sensitive a subject as tobacco or alcohol consumption, not to mention sexual habits, it could be difficult for a practitioner to ask about this topics directly and it might be stressful for the teenager to reply in a face to face relationship. Little by little, step by step, once the practitioner has discerned elements suggesting risk behaviours in the teenager's answers, he can broach more sensitive subjects. This type of indirect and progressively probing approach could enable the practitioner to proceed to direct screening by asking a teenager whether he has risky behaviors. Questioning on screen use could represent an approach to risk behavior that would complement other screening tests, such as the BITS (Binder \& Chabaud, 2004). In addition, dissemination of our results, along with the data in the literature, could encourage education officials to impose a limit of 2 hours/weekday of screen time. It should nonetheless be emphasized that in clinical practice, this amount of time need not be verified by a stopwatch; what matters most, after all, is the teenager's actual behaviour. In any event, the criteria we have applied require validation in a wider age range.

The above indications are sure to evolve as technology screens change and di- 
versify. The smartphone, on the other hand, is multi-functional, and the borders between its different uses remain imprecise. Taken as a whole, however, technology screens are constantly evolving, and their different sizes, shapes and functions are of less and less decisive importance; that is one reason why, in this study, we made no distinction between conventional telephones, smartphones and tablets. Future studies will need to take these diverse settings into account. With this in mind, we wish to suggest that what distinguishes the smartphone from the other screens is the way it can be used "on an impulse".

To conclude, in order to fully validate the interest of interrogation during a consultation on the time spent in front of screens, it would be necessary to study the amount of time spent during the week communicating on a smartphone as a warning sign for behavioral disorders.

\section{Acknowledgments}

The authors wish to thank the Rector of the Academy of Poitiers and theteams that conducted the survey in schools Marie-Thérèse Roux et Stéphane Robin. They wish to give particular thanks to the association Relais 17 for its support and Ms. Brigitte Drapt, for her investment in this study.

\section{Conflicts of Interest}

The author declares no conflicts of interest regarding the publication of this paper.

\section{References}

American Academy of Pediatrics, Council on Communications and Media (2013). Children. Adolescents, and the Media. Pediatrics.

http://pediatrics.aappublications.org/content/pediatrics/early/2013/10/24/peds.2013-26 56.full.pdf

Bigot, R., Croutte, P., \& Daudey, E. (2013). La diffusion des technologies de l'information et de la communication dans la société française (288 p.). Enquête Conditions de vie et Aspirations des Français. Credoc.

Binder, P., \& Chabaud, F. (2004). Dépister les conduites suicidaires des adolescents. Conception d'un test et validation de son usage (I) et (II). La Revue du Praticien Médecine Générale, 18, 576-580.

Browne, K. D., \& Hamilton-Giachritsis, C. (2005). The Influence of Violent Media on Children and Adolescents: A Public-Health Approach. The Lancet, 365, 702-710.

Busch, V., Manders, L. A., \& de Leeuw, J. R. (2013). Screen Time Associated with Health Behaviors and Outcomes in Adolescents. American Journal of Health Behavior, 37, 819-830. https://doi.org/10.5993/AJHB.37.6.11

Carson, V., Pickett, W., \& Janssen, I. (2011). Screen Time and Risk Behaviors in 10-to 16-Year-Old Canadian Youth. Preventive Medicine, 52, 99-103.

https://doi.org/10.1016/j.ypmed.2010.07.005

Chan-Chee, C. (2011). Hospitalisations pour tentatives de suicide entre 2004 et 2007 en France métropolitaine. Analyse du PMSI-MCO. Bull Epidemiol Hebd, 47-48, 492-496.

Christiansen, E., \& Jensen, B. F. (2007). Risk of Repetition of Suicide Attempt, Suicide or 
All Deaths after an Episode of Attempted Suicide: A Register-Based Survival Analysis. Australian \& New Zealand Journal of Psychiatry, 41, 257-265. https://doi.org/10.1080/00048670601172749

Crowne, D., \& Marlowe D. (1960). A New Scale of Social Desirability Independent of Psychopathology. Journal of Consulting Psychology, 24, 349-354. https://doi.org/10.1037/h0047358

Currie, C., Griebler, R., Inchley, J., Theunissen, A., Molcho, M., Samdal, O., \& Dür, W. (2010). Health Behaviour in School-Aged Children (HBSC) Study Protocol: Background, Methodology and Mandatory Items for the 2009/10 Survey. Edinburgh: CAHRU \& Vienna: LBIHPR. http://www.hbsc.org

Dalbudak, E. et al. (2013). Relationship of Internet Addiction Severity with Depression, Anxiety, and Alexithymia, Temperament and Character in University Students. $C y$ berpsychology, Behavior, and Social Networking, 16, 272-278. https://doi.org/10.1089/cyber.2012.0390

Eaton, D. K. et al. (2012). Youth Risk Behavior Surveillance-United States, 2011. Morbidity and Mortality Weekly Report, 61, 1-162. http://www.cdc.gov/mmwr/preview/mmwrhtml/ss6104a1.htm

Fitzpatrick, C., Burkhalter, R., \& Asbridge, M. (2019). Adolescent Media Use and Its Association to Wellbeing in a Canadian National Sample. Preventive Medicine Reports, 14, Article ID: 100867. https://doi.org/10.1016/j.pmedr.2019.100867

Fu, K. W., Chan, W. S., Wong, P. W., \& Yip, P. S. (2010). Internet Addiction: Prevalence, Discriminant Validity and Correlates among Adolescents in Hong Kong. The British Journal of Psychiatry, 196, 486-492. https://doi.org/10.1192/bjp.bp.109.075002

Grøntved, A. et al. (2015). Prospective Study of Screen Time in Adolescence and Depression Symptoms in Young Adulthood. Preventive Medicine, 81, 108-113. https://doi.org/10.1016/j.ypmed.2015.08.009

Ha, J. H., Chin, B., Park, D. H., Ryu, S. H., \& Yu, J. (2008). Characteristics of Excessive Cellular Phone Use in Korean Adolescents. CyberPsychology \& Behavior, 11, 783-784. https://doi.org/10.1089/cpb.2008.0096

Holtz, P., \& Appel, M. (2011). Internet Use and Video Gaming Predict Problem Behavior in Early Adolescence. Journal of Adolescence, 34, 49-58. https://doi.org/10.1016/j.adolescence.2010.02.004

INSEE (2012). Evolution et structure de la population, RP exploitations complémentaires. Institut National de la Statistique et des Etudes Economiques (France).

http://www.insee.fr/fr/themes/tableau_local.asp?ref_id=POP\&millesime=2012\&typgeo $=$ REG\&search $=54$

Jago, R. et al. (2014). Cross-Sectional Associations between the Screen-Time of Parents and Young Children: Differences by Parent and Child Gender and Day of the Week. International Journal of Behavioral Nutrition and Physical Activity, 11, 54. https://doi.org/10.1186/1479-5868-11-54

Jin, B., \& Park, N. (2013). Mobile Voice Communication and Loneliness: Cell Phone Use and the Social Skills Deficit Hypothesis. New Media \& Society, 15, 1094-1111. https://doi.org/10.1177/1461444812466715

Jousselme, C., Cosquer, M., \& Hasssler, C. (2015). Portraits d'adolescents: Enquête épidémiologique multicentrique en milieu scolaire en 2013 (182 p.). Paris: INSERM.

Kang, M. J., \& Lee, M. S. (2014). The Association of Depression and Suicidal Behaviors with Smartphone Use among Korean Adolescents. Korean Journal of Health Education and Promotion, 31, 147-158. https://doi.org/10.14367/kjhep.2014.31.5.147 
Kim, K. et al. (2006). Internet Addiction in Korean Adolescents and Its Relation to Depression and Suicidal Ideation: A Questionnaire Survey. International Journal of Nursing Studies, 43, 185-192. https://doi.org/10.1016/j.ijnurstu.2005.02.005

Kokkevi, A., Rotsika, V., Arapaki, A., \& Richardson, C. (2012). Adolescents' Self-Reported Suicide Attempts, Self-Harm Thoughts and Their Correlates across 17 European Countries. Journal of Child Psychology and Psychiatry, 53, 381-389. https://doi.org/10.1111/j.1469-7610.2011.02457.x

Leather, N. C. (2009). Risk-Taking Behaviour in Adolescence: A Literature Review. Journal of Child Health Care, 13, 295-304. https://doi.org/10.1177/1367493509337443

Lenhart, A. (2012). Pew Internet \& American Life Project-Teens, Smartphones \& Texting. Washington DC: Pew Research Center. http://www.pewinternet.org/files/old-

Lenhart, A., Hitlin, P., \& Madden, M. (2005). Pew Internet \& American Life Project-Teens and Technology. Washington DC: Pew Research Center.

Li, B., Friston, K. J., Liu, J., Liu, Y., Zhang, G., Cao, F., Su, L., Yao, S., Lu, H., \& Hu, D. (2014). Impaired Frontal-Basal Ganglia Connectivity in Adolescents with Internet Addiction. Scientific Reports, 4, 5027. https://doi.org/10.1038/srep05027

Maras, D. et al. (2015). Screen Time Is Associated with Depression and Anxiety in Canadian Youth. Preventive Medicine, 73, 133-138.

https://doi.org/10.1016/j.ypmed.2015.01.029

Ministère de l'Éducation Nationale, de l'Enseignement supérieur et de la Recherche, Enfants \& Internet. (2010). Baromètre 2009-2010. Un clic, déclic le Tour de France Des Etablissements Scolaires.

http://eduscol.education.fr/numerique/textes/rapports/societe-numerique/culture-num erique/2010/calysto

Nieman, P. (2003). Canadian Pediatric Society Statement: Impact of Media on Children and Youth. Paediatrics \& Child Health, 8, 301-306. https://doi.org/10.1093/pch/8.5.301

Niemz, K., Griffiths, M., \& Banyard, P. (2005). Prevalence of Pathological Internet use among University Students and Correlations with Self-Esteem, the General Health Questionnaire (GHQ), and Disinhibition. CyberPsychology \& Behavior, 8, 562-570. https://doi.org/10.1089/cpb.2005.8.562

Olson, C. K. (2004). Media Violence Research and Youth Violence Data: Why Do They Conflict? Academic Psychiatry, 28, 144-150. https://doi.org/10.1176/appi.ap.28.2.144

Pallanti, S., Bernardi, S., \& Quercioli, L. (2006). The Shorter PROMIS Questionnaire and the Internet Addiction Scale in the Assessment of Multiple Addictions in a High-School Population: Prevalence and Related Disability. CNS Spectrums, 11, 966-974. https://doi.org/10.1017/S1092852900015157

Rey-López, J. P. et al. (2012). Reliability and Validity of a Screen Time-Based Sedentary Behaviour Questionnaire for Adolescents: The HELENA Study. European Journal of Public Health, 22, 373-377. https://doi.org/10.1093/eurpub/ckr040

Rice, E., Winetrobe, H., Holloway, I. W., Montoya, J., Plant, A., \& Kordic, T. (2015). Cell Phone Internet access, Online Sexual Solicitation, Partner Seeking, and Sexual Risk Behavior among Adolescents. Archives of Sexual Behavior, 44, 755-763.

https://doi.org/10.1007/s10508-014-0366-3

Richards, R., McGee, R., Williams, S. M., Welch, D., \& Hancox, R. J. (2010). Adolescent Screen Time and Attachment to Parents and Peers. Archives of Pediatrics and Adolescent Medicine, 164, 258-262. https://doi.org/10.1001/archpediatrics.2009.280

Rideout, V. J., Roberts, D. F., \& Foehr, U. G. (2010). Generation M2: Media in the Lives of 8 -18-Year-Olds. 
http://kff.org/other/poll-finding/report-generation-m2-media-in-the-lives/

Villani, S. (2001). Impact of Media on Children and Adolescents: A 10-Year Review of the Research. Journal of the American Academy of Child \& Adolescent Psychiatry, 40, 392-401. https://doi.org/10.1097/00004583-200104000-00007

Whang, L. S., Lee S., \& Chang, G. (2003). Internet over-Users' Psychological Profiles: A Behavior Sampling Analysis on Internet Addiction. CyberPsychology \& Behavior, 6, 143-150. https://doi.org/10.1089/109493103321640338

Widyanto, L., \& McMurran, M. (2004). The Psychometric Properties of the Internet Addiction Test. CyberPsychology \& Behavior, 7, 443-450.

https://doi.org/10.1089/cpb.2004.7.443

Young, K. S. (1998). Internet Addiction: The Emergence of a New Clinical Disorder. $C y$ berPsychology \& Behavior, 1, 237-244. https://doi.org/10.1089/cpb.1998.1.237 